Peshawar Journal of Psychology and Behavioral Sciences, 2016, Vol. 2, No. 1, 59-70

\title{
Religiosity and Addiction Among Medical Students
}

\author{
Salma Rehman ${ }^{1}$ \& Madiha Asghar ${ }^{2}$ \\ Islamia College Peshawar
}

\begin{abstract}
The present study was aimed at exploring the relationship between the role of religiosity and drug addiction among medical students. In the present study the drug addicted medical students were compared to non-addicts on measures of adolescent alcohol and drug use and demographic information. Participants of the study consisted of two hundred $(\mathrm{N}=200)$ male and female students with the age range of $18-29$, including one hundred addicts $(n=100)$ and one hundred $(n=100)$ non addict medical students. Convenient sampling and snowball technique was used for collecting the data from medical students of Khyber Pakhtunkhwa, Pakistan. Responses from the different medical students were analyzed. The finding of the research indicated that those students who offered their prayers on regular basis were less likely to be prone to drug addiction as compared to those who did not offer prayers regularly.
\end{abstract}

Keywords. Addiction, religiosity, medical students, and prayers

Drug is a chemical agent that has medical value when ingested to the living body causes change in biological functions of the organism

\footnotetext{
${ }^{1}$ Lecturer, Department of Psychology, Islamia College Peshawar

${ }^{2}$ Assistant Professor, Department of Psychology, Islamia College Peshawar
} 
(Katzung \& Trevors, 2008). It leads to varying degrees of dependence or addiction if used illegally and without prescription of doctors.

Drug addiction is an irresistible and compulsive use of drug despite of awareness of the negative consequences that seriously impair the individual physical and mental health and those around them. Addiction results when individual consistently ingest substances such as (alcohol, opioids, hallucinogens, stimulants, sedatives, hypnotics, anti depressants and anxiolytics) either to avoid pain or for seeking pleasure.

There is difference between Substance abuse and drug addiction. DSM-5define Substance abuse as a compulsive use of a substance over a period of twelve months that causes serious personal, academic, social and legal complication for the individual, their immediate environment and society as a whole.

Different types of drug addiction are defined in the DSM-5 (2013), but it uses the terms substance abuse and substance dependency. Neither equates to addiction directly but rather, refers to harmful use of substances that impair individual daily life functioning. Addiction is both of psychological and behavioral type.

Religiosity is a composite and multidimensional construct within adolescent's substance use research. Researchers defined it in a variety of ways, which include private religiosity refers to interpersonal aspect of religiosity, personal religious beliefs and private practices such as offering prayers. Social religiosity refers to public activities such as mosque and church attendance (Krause \& Wulff, 2005; Nonnemaker et al., 2003; Simmel, 1997). Perceived religious support and comfort includes specific instrumental support refers to material offers to assist with tasks or money. (Chitwood et al., 2008; Dew et al., 2008; Marsiglia, Ayers, \& Hoffman, 2012; Nonnemaker, McNeely, \& Blum, 2003; Rew\& Wong, 2006; Yeung et al., 2009).

Research study revealed that individual attached to religious practices possessed religious beliefs and attitude are more likely to be 
healthy mentally and physically and will less prone toward smoking, alcohol and drug use (Kubzansky \& Maselko, 2006).

Research studies conducted on university students examined that religiosity is a protective measure against drug use. One of the pioneering studies on substance use among medical students was conducted in Brazil, Marilia, Sao Paulo showed that religiosity is a defensive measure against the use of alcohol and other drugs (Borini P, Oliveira CM, Martins MG, Guimarães RC, 1994). Those students who report that they attend religious practices on regular basis have norms and values that result in protective measures against drug use (Silva LV, Malbergier A, Stempliuk V A, Andrade AG 2004).

The present study is aimed at investigating the relationship of drug addiction and regularity in prayers among medical students. Persistent work overshadowing important activities of life including religious practices cause excessive stress and may compel an individual to be indulged into unhealthy activities.

\section{Objectives}

1. To study and compare the prevalence of drug addiction among medical students.

2. To investigate and compare prevalence of drug addiction on the basis of punctuality in prayers among medical students.

\section{Hypotheses}

1. Drug addiction will be high among those medical students who do not offer prayers regularly as compared to those who offer prayers regularly.

2. Females will be more regular in offering prayers and less prone to addiction as compared to males. 


\section{Method}

\section{Sample}

Total sample was comprised of two hundred $(\mathrm{N}=200)$ addicted and non-addicted medical students with the age range of 18-29 years $(\mathrm{M}=22.65, \mathrm{SD}=1.60)$ both males and females. All the participants of the study were Muslims Snow ball and convenient sampling technique was used because random sampling was not possible due to a variety of factors, such as accepting to be addict as medical student due to social pressures and stigma of addiction.

\section{Tools}

The following tools will be used in the study to measure both predicting and outcome variables

\section{Demographic data sheet}

Demographic sheet will be used to collect the demographic information about the subjects.

\section{Adolescent alcohol and drug involvement scale (AADIS)}

The adolescent drug involvement scale was developed by D.Paul Moberg in 1991.The scale comprises of total 14 items with five-point likert scale. The reliability of the scale is .85.Cutoff scores for diagnosing addiction is 37 and above.

\section{Procedure}


Before collecting the data formal permission was taken from the Principal of Medical Colleges. After identifying the addicted and nonaddicted medical students consent or permission was taken from medical colleges of Peshawar, Mardan and Abbotabad. Rapport was established and the subjects were briefed about the aims and objectives of the study. After the formal consent was taken, self-administered questionnaires and scales were given to the students. Instructions were readout to the subjects before administering the questionnaire and further explanations were also given to make sure the clarity of the questionnaire by respondents as required. The scales and questionnaires include demographic data sheet, adolescent alcohol and drug addict scale (AADIS).

\section{Results}

Table 1

Distribution of Addicts and Non-Addicts Based on Punctuality of Offering Prayers Daily ( $\mathrm{N}=200)$

\begin{tabular}{lcccl}
\hline & $\begin{array}{c}\text { Non-addict } \\
(\mathrm{n}=100)\end{array}$ & $\begin{array}{c}\text { Addict } \\
(\mathrm{n}=100)\end{array}$ & $\chi^{2}$ & $\begin{array}{c}\text { Odds } \\
\text { Ratio }\end{array}$ \\
\hline Not & 15 & 43 & & \\
regular & $(15.0 \%)$ & $(43.0 \%)$ & $(19.03) * * *$ & .234 \\
Regular & 85 & 57 & & \\
Total & $(85.0 \%)$ & $(57.0 \%)$ & & \\
& 100 & 100 & & \\
\hline
\end{tabular}

Note. $d f=1, *=p<.05, * *=p<.01 \& * * *=p<.001$

Table 1 shows crosstab between addicts and non-addict medical students on punctuality of offering prayers everyday. The result reveals that $85 \%$ of non-addict medical students offer their prayers on regular basis as compared to $57 \%$ of addict medical students. However $15 \%$ of non-addict medical students and $43 \%$ of addict medical students reports 
not regular in observing prayers. The results are highly significant at $\mathrm{p}<.001$ level.

Table 2

Gender Distribution of Addict and Non-Addict Medical Students Based on Not Punctually Offering Prayers Daily $(\mathrm{N}=58)$

\begin{tabular}{lcccc}
\hline Gender & $\begin{array}{c}\text { Non-addict } \\
(\mathrm{n}=15)\end{array}$ & $\begin{array}{c}\text { Addict } \\
(\mathrm{n}=43)\end{array}$ & $\chi^{2}$ & $\begin{array}{c}\text { Odds } \\
\text { Ratio }\end{array}$ \\
\hline Male & 7 & 41 & & \\
& $(46.7 \%)$ & $(95.3 \%)$ & $(18.471)^{* * *}$ & .043 \\
Female & 8 & 2 & & \\
Total & $(53.3 \%)$ & $(4.7 \%)$ & & \\
& 15 & 43 & & \\
\hline
\end{tabular}

Note. $d f=1, *=p<.05, * *=p<.01 \& * * *=p<.001$

Table 2 shows crosstab of gender between addicts and nonaddict medical students on not punctually offering prayers everyday. The result reveals that $95.3 \%$ of males addict medical students as compared to $4.7 \%$ of female addict medical students are not punctual in observing their prayers everyday. The results are highly significant at $\mathrm{p}<.001$ level.

Table 3

Gender Distribution of Addict and Non-Addict Medical Students Based on Punctually Offering Prayers Daily ( $\mathrm{N}=142)$

\begin{tabular}{lcccc}
\hline Gender & $\begin{array}{l}\text { Non-addict } \\
(\mathrm{n}=85)\end{array}$ & $\begin{array}{c}\text { Addict } \\
(\mathrm{n}=57)\end{array}$ & $\chi 2$ & Odds Ratio \\
\hline \multirow{3}{*}{ Male } & 43 & 46 & & \\
& $(50.6 \%)$ & $(80.7 \%)$ & \\
\hline
\end{tabular}




\begin{tabular}{lcccc}
\hline \multirow{2}{*}{ Female } & 42 & 11 & $(13.22)^{* * * *}$ & .245 \\
\multirow{2}{*}{ Total } & $(49.4 \%)$ & $(19.3 \%)$ & & \\
& 85 & 57 & & \\
& $(100.0 \%)$ & $(100.0 \%)$ & \\
\hline
\end{tabular}

Note. $d f=1, *=p<.05, * *=p<.01 \& * * *=p<.001$

Table 3 shows crosstab of gender difference between addicts and non-addict medical students on punctuality in offering prayers everyday. The result reveals that $80.7 \%$ of male addict medical students as compared to $19.3 \%$ of female addict medical students are not punctual in observing their prayers everyday. The results are highly significant at $\mathrm{p}<.001$ level.

Table 4

Mean Difference, Standard Deviation, t-Value of Medical Students Offering Prayers Regularly on Scores of Addiction Scale (N=200)

\begin{tabular}{|c|c|c|c|c|c|c|c|c|}
\hline \multicolumn{2}{|c|}{$\begin{array}{c}\text { Yes } \\
(\mathrm{n}=58)\end{array}$} & \multicolumn{2}{|c|}{$\begin{array}{c}\text { No } \\
(\mathrm{n}=142)\end{array}$} & \multirow[b]{2}{*}{$\mathrm{t}(198)$} & \multirow[b]{2}{*}{$\mathrm{p}$} & \multicolumn{2}{|c|}{ CI $95 \%$} & \multirow{2}{*}{$\begin{array}{c}\text { Cohen's } \\
\text { D }\end{array}$} \\
\hline $\mathrm{M}$ & SD & $\mathrm{M}$ & SD & & & LL & UL & \\
\hline 28.29 & 18.50 & 43.84 & 18.86 & 5.36 & .001 & 2.78 & 9.83 & .83 \\
\hline
\end{tabular}

Table 4 shows independent sample t-test for addict and nonaddict medical students offer prayers everyday on the scores of addiction scale. Medical students who punctually observe prayers everyday $(\mathrm{M}=28.2, \mathrm{SD}=18.50)$ scored significantly lower on addiction scale as compared to medical students who do not observer prayers regularly $(\mathrm{M}=43.84, \mathrm{SD}=18.86), \mathrm{t}(198)=5.36$, with mean difference $15.55, \mathrm{p}$ $<.001$; CI 95\% [2.78, 9.83]. The effect size 0.83 for this analysis was exceeding Cohen's (1988) convention for large effect size (.80).

Table 5

Peshawar Journal of Psychology and Behavioral Science, 2016, Vol. 2. No. 1, 59-70 
Mean Difference, Standard Deviation, t-Value of Addicted Medical Students Offering Prayers Regularly on Addiction Scale ( $\mathrm{N}=100)$

\begin{tabular}{|c|c|c|c|c|c|c|c|c|}
\hline \multicolumn{2}{|c|}{$\begin{array}{c}\text { Yes } \\
(\mathrm{n}=57)\end{array}$} & \multicolumn{2}{|c|}{$\begin{array}{c}\text { No } \\
(\mathrm{n}=43)\end{array}$} & \multirow[b]{2}{*}{$\mathrm{t}(198)$} & \multirow[b]{2}{*}{$\mathrm{p}$} & \multicolumn{2}{|c|}{ CI 95\% } & \multirow{2}{*}{$\begin{array}{c}\text { Cohen's } \\
\text { D }\end{array}$} \\
\hline $\mathrm{M}$ & SD & $\mathrm{M}$ & SD & & & $\mathrm{LL}$ & UL & \\
\hline 49.58 & 9.58 & 54.21 & 7.57 & 2.61 & .05 & .00 & .24 & .52 \\
\hline
\end{tabular}

Table 5 shows independent sample t-test for addict medical students offer prayers regularly on the score of addiction scale. Addict medical students who do not punctually observe prayers everyday ( $\mathrm{M}=$ 54.21, $\mathrm{SD}=7.57$ ) scored significantly higher on addiction scale as compared to addict medical students who observer prayers regularly $(\mathrm{M}=49.58, \mathrm{SD}=9.58), \mathrm{t}(198)=2.61$, with mean difference 4.63, $\mathrm{p}<.05$; CI $95 \%[.00, .24]$. The calculated value of effect size 0.52 for this analysis shows medium effects size as per the Cohen's (1988) convention.

Table 6

Mean Difference, Standard Deviation, t-Value of Non-Addict Medical Students Offering Prayers Regularly on Addiction Scale ( $\mathrm{N}=100)$

\begin{tabular}{|c|c|c|c|c|c|c|c|c|}
\hline \multicolumn{2}{|c|}{$\begin{array}{c}\text { Yes } \\
(\mathrm{n}=85)\end{array}$} & \multicolumn{2}{|c|}{$\begin{array}{c}\text { No } \\
(\mathrm{n}=15)\end{array}$} & \multirow[b]{2}{*}{$\mathrm{t}(198)$} & \multirow[b]{2}{*}{$\mathrm{p}$} & \multicolumn{2}{|c|}{ CI 95\% } & \multirow{2}{*}{$\begin{array}{c}\text { Cohen's } \\
\text { D }\end{array}$} \\
\hline $\mathrm{M}$ & SD & $\mathrm{M}$ & SD & & & LL & UL & \\
\hline 14.01 & .10 & 14.13 & .51 & 1.97 & .01 & 1.11 & 8.14 & .54 \\
\hline
\end{tabular}

Table 6 shows independent sample t-test of non-addict medical students offer prayers everyday on the scores of addiction scale. Nonaddict medical students punctually observe prayers everyday $(M=14.01$, $\mathrm{SD}=.10)$ scored lower on addiction scale as compared to non-addict medical students not regular in observing prayers everyday $(\mathrm{M}=14.13$, $\mathrm{SD}=0.51), \mathrm{t}(198)=1.97$, with mean difference $-0.12, \mathrm{p}<.01$; CI $95 \%$ 
$[1.11,8.14]$. The calculated value of effect size 0.54 for this analysis shows medium effects size as per the Cohen's (1988) convention.

\section{Discussion}

Ahmed et al. (2011) examined that drug addicted medical students mostly used avoidant strategies (substance use) whereas nonaddicted used active strategies (religiosity coping) for dealing with their daily life stressors. The current study yielded consistent results with the findings of earliest studies conducted by Nonnemaker, McNeely \& Blum (2003) that there is significant relationship between stress and avoidant strategies (drug addiction) in addicted group. Medical students feel stressed because of the tough study schedules, stressful work environment and to cope-up with these stressors addict medical students most of the time used avoidant strategies. The currents study found that the prevalence of drug addiction was low among those medical students who offered prayers five times a day (religious coping).

Current study found that female medical students mostly use religious coping as compared to male student and there the ratio of addiction is low among female students as compare to male medical students.

The current study yielded consistent results with earliest research studies that students with high religiosity involvement were less likely to prone toward substance use and to have experienced the consequences of substance use than those with low religiosity (Johnson, Tomkins, \& Webb, 2002).

The present study showed consistent results with previous studies that social religiosity, includes masjid or church attending and private religiosity includes, offering prayers having a great protective effect in experimental users of drugs (Nonnemaker et al., 2003). Since mental health is a complex phenomenon and can not be associated to only one aspect, that is why drug free healthy life may not be only limited to religiosity and offering prayers regularly, as there several other factors effecting the mental health of the people. However, the findings

Peshawar Journal of Psychology and Behavioral Science, 2016, Vol. 2. No. 1, 59-70 
of the present study showed significant difference on scores of addiction between addict and non-addict medical students on the basis of religiosity.

\section{Limitation}

- Small size of the sample and diversity of the characteristics sample due to inclusion of the participants from all the major public medical colleges of Khyber Pakhtunkhwa limits the generalizability of the findings to the entire population of medical students in Pakistan.

- Religiosity was measured through single item asking about offering prayers regularly, which may raise questions about the other important aspects of religiosity and religiosity may not be limited to offering prayers only.

\section{Recommendations}

- Study conducted on a wide range including medical colleges from all provinces of Pakistan may improve better generalizability of the findings.

- A standardized scale of religiosity indigenously tested may help in finding association between addiction and religiosity, similarly the difference between addict and non-addicts will be better understood.

\section{Conclusion}

This research studied the religious basis of drug addiction among medical students. Regularly performing prayers prevent drug addiction as the non-addicts reported more regular praying then addicted group. It was therefore concluded that religiosity does have a role in healthy life 
style and dealing with life stressors. It is suggested that further research studies are needed in this area so that the problem of drug addiction may be effectively dealt with to prevent the health professional from the drug addiction. Addiction is the curse of the society and threat to wellbeing of the mental health of the health professionals.

\section{References}

American psychiatric association (2013). Diagnostic and statistical manual of mental disorder, $5^{\text {th }}$ edn. American Psychiatric Association, Washington, DC: Dollen and Sons Company.

Katzung, G. B., Trevors, J. A., Masters, S. (2008). Pharmacology: Explainationnadboard Reviews ( $8^{\text {th }}$ ed.). printed in United State of America.

Van der Meer Sanchez Z, De Oliveira LG, Nappo SA. Religiosity as a protective factor against the use of drugs. Subst Use Misuse. 2008;43(10):1476-86.

Tavares BF, Beria JU, Lima MS. Prevalência do uso de drogas e desempenho escolar entre adolescentes. Rev SaúdePública. 2001;35(2):150-8

Dalgalarrondo P, Soldera MA, CorrêaFilho HR, Silva CA. Religion and drug use by adolescents. Rev Bras Psiquiatr. 2004;26(2):82-90

Sanchez ZM, Opaleye ES, Chaves TV, Noto AR, Nappo SA. God forbids or mom disapproves? religious beliefs that prevent drug use among youth. J Adolesc Res. 2011;26(5):591-616.

Borini P, Oliveira CM, Martins MG, Guimarães RC. Padrão de uso de bebidasalcoólicas de estudantes de medicina (Marília, São Paulo): parte 1. J Brasileiro de Psiquiatria. 1994;43(2):93-103.

Silva LV, Malbergier A, Stempliuk V A, Andrade AG. Factors associated with drug and alcohol use among university students. Rev SaúdePública. 2006;40(2):280-8.

Blay SL, Batista AD, Andreoli SB, Gastal FL. The relationship between religiosity and tobacco, alcohol use, and depression in an elderly 
community population.Am J Geriatr Psychiatry. 2008;16(11):93443. Michalak L, Trocki K, Bond J. Religion and alcohol in the U.S. National Alcohol Survey: how important is religion for abstention and drinking. Drug Alcohol Depend. 2007;87:268280. doi: 10.1016/j.drugalcdep.2006.07.013.

Chitwood DD, Weiss ML, Leukefeld C. A systematic review of recent literature on religiosity and substance use. Journal of Drug Issues. 2008;38:653-688.

Nonnemaker JM, McNeely CA, Blum RW. Public and private domains of religiosity and adolescent health risk behaviors: Evidence from the National Longitudinal Study of Adolescent Health. Social Science \& Medicine. 2003;57:2049-2054.

Dew RE, Daniel SS, Armstrong TD, Goldston DB, Triplett MF, Koenig HG. Religion/spirituality and adolescent psychiatric symptoms: A review. Child Psychiatry and Human Development. 2008;39:381398.

Martino SC, Ellickson PL, McCaffrey DF. Developmental trajectories of substance use from early to late adolescence: A comparison of rural and urban youth. Journal of Studies on Alcohol and Drugs.2008; 69:430-440.

Marsiglia FF, Ayers SL, Hoffman S. Religiosity and adolescent substance use in Central Mexico: Exploring the influence of internal and external religiosity on cigarette and alcohol use. American Journal of Community Psychology. 2012; 49: 87971 